\title{
Multimedia Development in 1st Grade of Mu'allimin Madrasa of Muhammadiyah Yogyakarta, Indonesia
}

\author{
Muhammad Lailan Arqam \\ Ahmad Dahlan University, Yogyakarta, Indonesia \\ arqam1503@gmail.com
}

\begin{abstract}
The development of multimedia learning in Kemuhammadiyahan subjects, is one of the efforts made in improving the quality of learning processes and results. With this multimedia learning, it is expected to be able to overcome the problems at hand. This research was conducted at Mu'allimin Madrasa of Muhammadiyah which is located at Letjend Street. S. Parman no. 68 Yogyakart. The result shows that development of multimedia learning in Kemuhammadiyahan subjects is done by developing several aspects, namely: (a) Text Aspect; (b) Color Aspects; (c) Animation and Image Aspects; (d) Material Aspects; (e) Sound Aspects; (f) Interactive aspects.
\end{abstract}

Keywords : multimedia; development; Mu'allimin Madrasa of Muhammadiyah Yogyakarta

\section{Introduction}

Multimedia is a combination of text, graphics, audio, motion pictures (animations and videos) that can make the user attractive. With these advantages, making multimedia is used in the learning process. Through multimedia, users / learners do not only involve existing sensory abilities and have the power of attraction alone, but can also provide good stimulants in responding to comprehensively taught knowledge.

This is reinforced by Sri Anitah (2009: 61) in a book called Media learning said that: multimedia systems may consist of a combination of traditional media that is connected to a computer to present text, graphics, images, sound, and video. Multimedia involves more than just integrating these forms into a structured program, which consists of elements complementing one another.

Kemuhammadiyahan as one of the subjects in the Mu'allimin Muhammadiyah Yogyakarta Madrasah, these subjects have an important role to play in relation to the vision and mission of the Madrasah, which declared itself to be a prospective school cadre of the Muhammadiyah community organizations in Indonesia. However, in the field, the Kemuhammadiyahan learning process still seems tedious, passive and boring. This is clearly seen with no use of media and variations in methods in learning and learning models that are still teacher-centered (teacher centered). The teaching material book is the only learning guide for students in learning. For this reason, in this study, researchers wanted to develop computer-assisted learning media, which was later termed as multimedia learning kemuhammadiyahan.

The development of multimedia learning in Kemuhammadiyahan subjects, is one of the efforts made in improving the quality of learning processes and results. With this multimedia learning, it is expected to be able to overcome the problems at hand. Like the monotony of the learning process, the learning model is still teacher-centered, students who are passive in learning, lack of variations in learning and saturation when learning takes place.

Multimedia learning is designed using development principles that pay attention to various aspects that affect the success of learning. In hopes of making students motivated in 
learning, optimizing the potential of the body and soul of students when learning takes place. And can be used according to the level of speed of thinking of students in understanding the material and needs.

\section{Review of Literature}

\subsection{Theory of Learning as a Learning Platform according to Behavioristic Theory}

According to the theory of behavoristik (Asri Budiningsih, 2005: 20) explained that learning is a change in behavior as a result of the interaction between stimulus and response. According to MR, Simonson and Ann., Thompson, (1994: 28) behaviorism is based on the principle that instruction should be designed to produce observable and quantifiable behaviors in the learner (Behaviorism is based on the principle that learning should be designed to produce learners' behavior can be observed and measured).

Someone is considered to have learned something if he has been able to show changes in his behavior from not understanding to understanding. So the most important thing is input or input in the form of stimulus and output or output in the form of response. This theory is based on the principle that learning should be designed to produce observable behavior of students. In other words, changes in behavior in this theory can be measured and changes can be seen clearly. Like students who previously did not know and were unable to do something, after going through the learning process he became aware and could do something. This theory by experts has been used as the initial basis in developing computer-based learning designs, and has been a driving force for developers to develop learning designs.

In detail the application of behavioristic theory in learning includes the following steps (Asri Budiningsih, 2005: 29): (a) determine learning goals; (b) analyzing the current class environment including identifying the initial abilities (entry behavior) of students; (c) determine the subject matter; (d) solving subject matter into small sections, covering subject matter, subject matter, topic, etc .; (e) present the subject matter; (f) provide stimulus, either in the form of direct verbal questions, tests / quizzes, exercises, and assignments; (g) observe and assess responses given by students; (h) providing reinforcement, either in the form of positive or negative reinforcement, or punishment; (i) provide a new stimulus; (j) observe and review responses given by students; (k) provide further reinforcement or punishment; (l) so on; and (m) evaluation of learning outcomes.

\subsection{Multimedia}

N., Chapman \& J., Champman, (2004: 8) states that the form of multimedia as a message delivery tool is divided into two, namely online delivery and offline delivery. The definition of multimedia that uses a network to convey information from one computer or server machine that is the center for storing data to other networks, both local networks within an organization and the internet, is called the online delivery system. Whereas, what is meant by offline delivery is multimedia stored by using a removable storage device or packaging. The storage device must be able to store large data in accordance with the characteristics of multimedia data, such as DVDs and CD-Roms.

Multimedia is a tool, method, and approach that is used to create more memorable communication between educators and students in the learning process created. In multimedia students not only get teaching material as knowledge material that must be mastered, but also 
can learn a science based on the interests, talents, pleasure, knowledge, and emotions of students. This is what makes multimedia superior to other media.

Multimedia products can be multimedia software or distance learning devices. Because multimedia can replace the role of educators. In other words, without the presence of educators, students can still learn. J.D., Flecter, (2007) provides opinions on distance learning as a form of learning that can distribute messages from educators to students without having to face to face. This makes learning not limited to place and time.

Development research conducted aims to produce multimedia software. Multimedia learning software that is produced is expected in the process of its use can have accuracy with the purpose of learning, can be operated easily, educators have the skills to use it, and according to the level of ability of students. Through the use of multimedia in learning learning can improve the quality of the process and learning outcomes.

\subsection{Classification of Learning Media}

According to Rudi and Cepi (2008: 13-22) there are many variations in the classification of learning media which are grouped into seven groups, namely: First Group; (a) Graphic Media, is a visual media that presents facts, ideas and ideas through the presentation of words, sentences, numbers, and symbols / images. Graphics are usually used to attract attention, clarify the presentation of ideas, and illustrate facts so that they are interesting and easy to remember. Including graphic media are graphics, diagrams, charts, sketches, posters, flannel boards, and bulletin boards. (b) Print Material Media, is the visual media that makes it through the process of printing / printing or offset. This media presents its message through letters and images illustrated to clarify the message or information presented. This form of media is like; textbooks, modules and programmed teaching materials. (c) Silent Image Media, is visual media in the form of images produced through photography. This type of media is a photo.

Second group; Silent projection media, are projected visual media or media that project messages, where the projection results do not move. These types of media include; OHP / OHT, Opaque projector, slides, and filmstrip. Third group; Audio media, is the media whose delivery of messages can only be received by the sense of hearing. This message or information is poured into auditive in the form of words, music, and sound effects. Fourth group; Silent audio-visual media, are media whose delivery of messages can be received by the sense of hearing and sight, but the resulting image is a still image or a little element of motion. These types of media include sound slide media, sound strip films, and sound pages.

Fifth group; Films, often referred to as motion pictures, are series of still images (still pictures) that slide quickly and projected to give the impression of life and movement. In the film presents audiovisual and moving messages. Therefore, the film gives an impressive message to the audience. Sixth group; Television, this media is the same as a film that displays audiovisual messages and moves. What distinguishes this media from its open type factor (open boardcast television), limited (cole circuit televirion / CCTV) and video-cassete recorder (VCR).

Seventh group; Multimedia, is a delivery system that uses various types of learning materials consisting of printed, audio and audiovisual materials. This type of media is object media and interactive. According to Heinich, Molenda, Russel, Smaldino (1996: 8) states that there are several media that can be used in learning activities: 
a. Non-projected media, such as pictures / photos, diagrams, exhibitions, and models.

b. Projected media, such as: slides, filmstrips, OHPs, and projected computers.

c. Audio media (audio media), such as: tapes and CDs.

d. Motion audio (moving media), such as: videos and movies.

e. Computer-mediated instruction.

f. Computer-based multimedia and hypermediai (computer-based and hypermedia multimedia)

g. Media, such as radio and television used in distance learning.

\subsection{Use of Macromedia Flash in Learning Multimedia Development}

In this study, multimedia products were developed using flash programs. The Macromedia Flash program is a multimedia graphics program and animation that can be used to create interactive web applications. Kok Yung, (2006: vii) revealed that Flash is one of the most popular animation programs nowadays, because something related to two-dimensional animation can be done easily on this program, with flash, people can make images as if live and more real.

Romi Satriawahono (2006) revealed some of the benefits of macromedia flash, including:

a. Animation, applications from Macromedia Flash can add animated elements properly

b. Games, Many games are made using Macromedia Flash.

c. User interface, most web site designers use macromedia flash as a user interface.

d. Flexible message area, here is an area on a web page that is designed to display the information needed that allows changes in time

e. Rich internet applications, covering a broad spectrum that provides a user interface to display and control the manipulation of data delivery from the internet.

\section{Discussion}

This learning multimedia development research was conducted at Muhammadiyah Mu'allimin Madrasa, which is located at Letjend Street. S. Parman no. 68 Yogyakarta. The flagship Madrasah managed directly by the head of the Muhammadiyah persyarikatan center, established since 1920, carries the slogan as a Muhammadiyah cadre school, has experienced a ups and downs of long history travel from time to time.

Madrasa Mu'allimin of Muhammadiyah Yogyakarta is located right in the middle between Sindurejan Village, Patangpuluhan Village and Ketanggungan Village in Yogyakarta City. In general these Madrasas have been adequate with various facilities and advantages. The Madrasa area also looks beautiful with a variety of trees which makes the learning atmosphere more enjoyable. The Madrasah now stands on 2.5 ha of land in ten locations adjacent to each other with 19 permanent buildings, in the form of educational buildings and other supporting buildings which consist of: 4 (four) new buildings, mosques, libraries with a total collection of 35,528 copies, 26 classrooms, 10 student dormitory units with a capacity of 1,200 students, complete with various laboratories; from the Mathematics, Physics, Chemistry, Biology, Computer and Language, and Electronic Skills laboratories, meeting halls, general and dental polyclinics, boarding houses for directors and boarders, dormitory kitchens and madrasah cooperatives (www.muallimin.org). 
Mu'allimin Madrasah of Muhammadiyah has a total of 98 educators at the level of secondary / junior high and high school level. 65\% of educators are between 20-40 years old, and $35 \%$ are over 40 years old. In general, the mastery of information technology among Madrasah Mu'allimin of Muhammadiyah educators does not experience significant obstacles, moreover this Madrasah location is right in the middle of a city that holds as an education city in Indonesia. In other words, access and information is not new for educators, especially with a relatively young age who are very familiar with the development of information technology.

From the results of interviews and observations of researchers at Kaur. Teaching Madrasas, in the words of only 7 teachers who are not familiar with information technology, including the use of aplicable computers and tools, as well as technology-based learning media. The observations prove that Mu'allimin Madrasas of Muhammadiyah have a variety of quality improvement programs for their teaching staff, among these programs there are activities in the form of basic and secondary computer training for educators and education personnel who aim to be able to keep up with the rapid development of technology and information. There are also powerpoint training, adobe reader and macromedia flash for educators who aim to enable Madrasah educators to develop media through these programs. As well as computer-based learning administration training for homeroom teachers who demand homerooms to make computer-based education administration. In another program, there is also a periodic 6-month English language course training, especially for teaching staff who teach in multilingual classes of Mu'allimin Muhammadiyah Madrasas. This shows that the management support of Madrasah Mu'allimin of Muhammadiyah is very good in improving the quality of educators and education personnel, especially in the fields of technology and information. This activity spurs academics in an effort to qualify for superior Madrasas that can compete not just periodically nationally but also at the international level. This is also balanced with a variety of very complete facilities, both in several classrooms in the form of flat screen LCDs and TVs as well as computer laboratories, language laboratories, mathematical laboratories, physics laboratories, chemical laboratories, biological laboratories, electronic laboratories and skills laboratories. In fact, in 2010 the Social Sciences and Religion laboratory was started, which can improve the quality of students in their scientific fields.

At the stage of development of multimedia learning Kemuhammadiyahan begins with planning products to be developed. In this research on the development of Kemuhammadiyahan's multimedia learning, due to the limitations of the researchers' ability to develop multimedia with the main program Macromedia Flash 8, the researchers collaborated with an animation expert named Fathul Muin, who was still studying at the Faculty of Fine Arts. Indonesia Yogyakarta.

Early planning of product specifications to be developed does not change significantly. As stated in chapter III above, the expected product specifications are as follows:

a. Multimedia learning developed was packaged in the form of compact disks (CDs) using professional macromedia flash 8 as the main software and other programs needed as supporters. And can be stored on a computer hard disk and flashdisk.

b. The use of multimedia learning allows students to learn more easily because they are filled with color, music, film, and animation. And includes competency standards, basic 
competencies, and indicators. Products can be used flexibly according to the wishes of students and equipped with learning exercises / evaluations.

c. Multimedia learning uses text, images, movies, animations, color combinations, and background music as needed, so that it can facilitate understanding, attention, and fun.

d. Multimedia learning can be used for independent individuals, as well as classics according to the availability of a number of computers. Or it can also be used with the help of a liquid crystal display (LCD) projector.

e. This compact disk (CD) learning product operation requires a computer that has software and hardware specifications as follows:

1) an Intel Pentium III processor 450 megahertz,

2) a minimum of 10 gigabytes of hard drive,

3) compact disk read only memory (CD-ROM) $52 \mathrm{X}$ speed drive,

4) 128-megabyte random access memory (RAM),

5) 32 megabyte video graphics array (VGA),

6) monitor resolution of $1024 \times 768$ pixels with 32 bit color depth,

7) active speakers, and

8) Microsoft Windows 98, Windows XP or Windows Vista Home Premium operating systems.

After going through a series of development trips, learning multimedia products underwent changes due to technical problems and suggestions from animation experts. The change was seen in the addition of the Swish Max program, and Cool Edit Pro 2.1. As well as not included competency standards, basic competencies, and indicators according to the advice of media experts, but still replaced with more general terms of learning objectives. The same thing was also conveyed by the material expert, who said the standards of competency, basic competency, and indicators were not relevant to the students. Because instructional language is too rigid and boring for students. For this reason, he gave suggestions to be replaced with learning objectives so students know the goals and expectations of learning outcomes after using multimedia learning that has been developed. Through these two suggestions, the researcher gives a learning goal item that explains the expectations of learning outcomes after using multimedia that has been developed. To maintain the interactivity of the media and increase student motivation in learning.

The following product specifications are the results of the development of multimedia learning that has been developed:

a. Multimedia learning developed was packaged in the form of compact disks (CDs) using professional macromedia flash 8 as the main software and supporting programs in the form of Swish Max, Cool Edit Pro 2.1, Corel Draw 12 Graphic Suite, and Microsoft Office Word. And can be stored on a computer hard disk and flashdisk because the multimedia capacity that has been developed is relatively small at 4.05 Megabytes.

b. Multimedia that has been developed has been equipped with colors that attract attractiveness, music that inspires the condition of students to be more energetic, films as an additional reference and entertainment, as well as interesting animations / images that make learning conditions easier and more comfortable. This product can be used flexibly according to the wishes of students and equipped with learning evaluation in the final stages of learning. 
c. Multimedia learning can be used for individuals independently, as well as classically according to the availability of a number of computers. Or it can also be used with the help of a liquid crystal display (LCD) projector.

d. In order to smooth the operation of the learning multimedia that has been developed this requires a computer that has software and hard specifications as a minimum as follows:

1) Intel Pentium III processor 450 megahertz,

2) A minimum hard drive of 10 gigabytes,

3) Compact disk read only memory (CD-ROM) $52 \mathrm{X}$ speed drive,

4) Random access memory (RAM) of 128 megabytes,

5) Video graphics array (VGA) 32 megabytes,

6) Monitor resolution of 1024 x 768 pixels with 32 bit color depth,

7) Active speakers, and

8) Microsoft Windows 98, Windows XP or Windows Vista Home Premium operating systems.

Furthermore, changing the product that the researcher develops is by changing the font of the letter from Arial planned, to Comic Sans MS. This change is deemed necessary to provide students with comfort in reading and not make an official impression, too serious, and monotonous. Because comic font characters are more familiar with the characteristics of children aged 12-15 years. While in the selection of colors, researchers took brighter colors with a brownish background that had been arranged at a slightly dim light level that depicted the past, this is in accordance with the contents of the material about the history of Muhammadiyah. This color choice was changed from the initial planning which was designed using yellow, green, red, and green background colors as the basic colors in Muhammadiyah. The next change is the addition of the multimedia learning menu, in the initial planning researchers did not use the film / video menu as one of the additional reference facilities. The menu of this film was raised because it followed the advice of material experts who argued that the need for additional references for students in Muhammadiyah's historical material. And also an entertainment that has educational value for students.

\section{Conclusion}

The learning process of Kemuhammadiyahan subjects has been going in one direction by frequently using the lecture method, still rarely using the media, and never using multimedia learning. This process experiences saturation and decrease in interest and student learning motivation. Development of multimedia learning in Kemuhammadiyahan subjects is done by developing several aspects, namely: (a) Text Aspect; (b) Color Aspects; (c) Animation and Image Aspects; (d) Material Aspects; (e) Sound Aspects; (f) Interactive aspects. By using multimedia learning on kemuhammadiyahan class I subjects at the Madrasah Mu'allimin of Muhammadiyah, it is effective in improving the learning process and results. 


\section{References}

Anas Sudijono. 2001. Pengantar Statistik Pendidikan. Jakarta: PT. Raja Grafindo Persada.

Arief Sadiman. 2003. Media Pendidikan. Jakarta: PT. Raja Grafindo Persada.

Arief Sadiman. 2001. Interaksi dan Motivasi Belajar Mengajar. Jakarta: PT. Raja Grafindo Persada.

Asri Budiningsih. 2003. Belajar dan Pembelajaran. Yogyakarta: Fakultas Ilmu Pendidikan. UNY.

Asri Budiningsih. 2005. Belajar dan Pembelajaran. Jakarta: PT. Rineka Cipta

Azhar Arsyad. 2003. Media Pembelajaran. Jakarta: Rajawali pers.

Bachtiar Sjaiful Bachri. 2002. Pengembangan bahan pembelajaran berbantuan komputer untuk memfasilitasi belajar mandiri dalam mata kuliah desain pesan pada program S-1 Teknologi Pendidikan Universitas Negeri Surabaya. Tesis: UNS

Chapman, N. \& Chapman, J., 2004. Digital multimedia (Second Edition). London: John Wiley \& Sons, Ltd.

Constantinescu, A.I., 2007. "Using technology to assist in vocabulary acquisition and reading comprehension". page 5. The internet TESL Journal, vol. XIII, No.2. from http://iteslj.org/Articles/Constantinescu-Vocabulary.html

Degeng, I Nyoman Sudana. 1989. Ilmu pengajaran taksonomi variabel. Jakarta: Depdikbud

Depdikbud. 1988/1989. Pedoman Penilaian Media Pendidikan. Jakarta: Depdikbud. Direktorat Sarana Pendidikan.

DePorter Bobbi \& Mike Hernacki, 2000. Quantum Learning. Bandung: Kaifa.

Djauhar Siddiq. 2005. Pembelajaran Visual Model Video Critique. Majalah ilmiah pembelajaran, 1, 57-72

Flecter, J.D. 2007. Learning Any Time Any Where: Advanced Distributed Learning and The Changing Face of Education. Educational Research Association, 36, 96-102

Gall Borg, Walter, and Meredith Damien, 1989. Educational Research. New York \& London : Longman.

Heinich, Molenda, Russel, Smaldino. 1996. Instructional Media and Technologies for Learning. New Jersey: Printice-Hall, Inc. A Simon \& Schuster Company.

Http://www.pustaka.usm.my/docushare/dsweb/GetRedition/Document=12907/ htm

Kok Yung. 2006. Teknik Profesional Flash MX 2004. Jakarta: Alex Media Komputindo.

M. Suyanto. 2005 Multimedia alat untuk Meningkatkan Mutu Bersaing. Yogyakarta: Andi offset.

Masnur Muslich. 2007. KTSP. Pembelajaran berbasis kompetensi dan kontekstual. Jakarta: Bumi Aksara.

Muhibbin Syah. 1996. Psikologi pendidikan: suatu pendekatan baru. Bandung: Remaja Rosdakarya.

Onong Uchjana Effendy. 2001. Ilmu Komunikasi Teori dan Praktek. Bandung: PT. Remaja Rosdakarya.

Phillips, Rob. 1997. The Developer's Handbook to Interactive Multimedia (A Practical Guide for Educational Appications). London: Kogan Page.

Romi Satriawahono. 2006. Media pembelajaran dalam Aspek Perangkat Lunak. www.romisatriawahono 
Rudi dan Cepi. 2008. Media Pembelajaran. Hakikat, Pengembangan, Pemanfaatan, dan Penilaian. Bandung: CV. Wacana Prima.

S H Lee, \& E. Boling. 1999. Screen Design Guidelines for Motivation in Interactive Multimedia Instruction : A Survey and Framework for Designer. Educational Technology. May-June.

Seels Barbara B and Richey, Rita C. 1994. Instructional Technology: The Definition and Domains of the Field. Washington, DC: Associations for Educational Communication and Technology (AECT).

Simonson, M.R. \& Ann. Thompson. 1994. Educational Computing Foundations. New York: Macmillan College Publishing Company.

Snyder, L.T. 1996. Multimedia \& Learning: where's the connection? Developments in business simulation \& experiential exercises, Volume 23. http://sbaweb.wayne.edu/absel/bkl/vol.23/23bp.pdf.

Sri Anitah. 2008. Media Pembelajaran. Solo: UNS Press.

Suciati \& Prasetya Irawan. 2001. Teori belajar dan motivasi . Pusat antar Universitas untuk peningkatan dan pengembangan aktivitas instruksional. Jakarta: Depdiknas Ditjen Pendidikan Tinggi.

Sugiono. 2008. Metode penelitian pendidikan (pendekatan kuantitatif, kualitatif dan $R \& D$. Bandung : PT. Alfabeta.

Suharsimi Arikunto. 1998. Prosedur Penelitian. Jakarta: Rineka Cipta.

Sukarno. 2009. Pengembangan multimedia pembelajaran untuk meningkatkan kemampuan menulis teks berita siswa SMP. Yogyakarta: Tesis UNY.

Sukmadinata. 2006. Metode penelitian pendidikan. Bandung : Program Pascasarjana Universitas Pendidikan Indonesia PT. Remaja Rosdakarya.

Sumarjana. 2008. Pengembangan multimedia interaktif pengenalan alat music tradisional gamelan jawa gaya Yogyakarta. Yogyakarta: Tesis UNY.

Tim Penulis UPI. 2007. Ilmu dan Aplikasi Pendidikan. Bandung : PT. Imperial Bhakti Utama.

Undang-Undang SISDIKNAS. (UU RI No. 20 Th.2003). Redaksi Sinar Grafika. Jakarta: Sinar Grafika.

Web quest. Cognitive learning theory. Tahun 2007 dari alamat http://suestudent.syr.edu/ebarrtt/ide621/cognitive/html.

Woolfolk, A.E. 1995. Educational psychology. Sixth Edition. Boston : Allyn and Bacon

Zaden, J.W. and Pace, A.J. 1984. Educational psychology in theory and practice. Second Edition New York : Random House, Inc. 